\title{
HUBUNGAN LINGKAR PINGGANG DENGAN PROFIL LIPID PADA PASIEN DIABETES MELITUS TIPE 2
}

\author{
${ }^{1}$ Mentari Simbar \\ ${ }^{2}$ Karel Pandelaki \\ ${ }^{2}$ M.C.P Wongkar \\ ${ }^{1}$ Kandidat Skripsi Fakultas kedokteran Universitas Sam Ratulangi Manado \\ ${ }^{2}$ Bagian Ilmu Penyakit Dalam RSUP Prof. Dr. R.D. Kandou Manado
}

\begin{abstract}
Waist circumference is often used to evaluate abdominal fat mass. Waist circumference is correlated with abdominal mass and is a predictor of type 2 diabetes mellitus compared to BMI. Diabetes Mellitus Type 2 (T2DM) is more common in individuals with overweight and obesity. T2DM is not only occured due to carbohydrate metabolism disorder of lipid metabolism but also due to dyslipidemia. Dyslipidemia caused by substances called lipoprotein VLDL (Very Low Density Lipoprotein) or triglycerides, decreased HDL cholesterol (High Density Lipoprotein) and the formation of small dense LDL (Low Density Lipoprotein) which are atherogenic. This study aimed to determine the relationship of waist circumference with the lipid profile in T2DM patients Prof. R.D. Kandou Hospital Manado. This was a descriptive cross sectional analytic study. There were 53 respondents that met the inclusion criteria. This study was conducted for three months starting from September - November 2013 in the Endocrine Clinic. Conclusions: There was no significant correlation between waist circumference and total cholesterol, LDL, and triglycerides levels. However, there is a significant correlation between waist circumference and HDL levels.

Keywords: Waist circumference, total cholesterol, HDL, LDL, Triglycerides, T2DM
\end{abstract}

\begin{abstract}
Abstrak: Lingkar pinggang sering digunakan sebagai penilai massa lemak abdominal, karena lingkar pinggang berkorelasi dengan massa lemak abdominal dan merupakan prediktor Diabetes Melitus Tipe 2 (DMT2) yang paling kuat dibandingkan dengan IMT. DMT2 lebih sering terjadi pada individu dengan berat badan lebih dan obesitas. Pada DMT2 bukan saja terjadi gangguan metabolisme karbohidrat melainkan juga terdapat metabolisme lipid, keadaan ini disebut dislipidemia. Dislipidemia terjadi akibat gangguan metabolisme lipoprotein yaitu Very Low Density Lipoprotein (VLDL), trigliserida, penurunan kolesterol High Density Lipoprotein (HDL), dan terbentuknya small dense Low Density Lipoprotein (LDL) yang bersifat aterogenik. Penelitian ini bertujuan untuk mengetahui hubungan lingkar pinggang dengan profil lipid pada pasien DMT2 di RSUP Prof. R.D. Kandou Manado. Jenis penelitian ini ialah deskriptif analitik dengan pendekatan cross sectional. Responden penelitian sebanyak 53 pasien yang memenuhi kriteria inklusi. Penelitian ini dilakukan selama tiga bulan yaitu dari bulan September - November 2013 di Poliklinik Endokrin Bagian/SMF Ilmu Penyakit Dalam RSUP. Prof. R.D. Kandou Manado. Simpulan: Tidak terdapat hubungan yang bermakna antara lingkar pinggang dengan kadar kolesterol total, kadar LDL, dan trigliserida. Terdapat hubungan bermakna antara lingkar pinggang dan kadar HDL.
\end{abstract}

Kata kunci: Lingkar Pinggang, Kolesterol Total, HDL, LDL, Trigliserida, DMT2

Obesitas saat ini merupakan masalah global dan mewabah diseluruh dunia. Insidensi obesitas di negara-negara berkembang makin meningkat. Prevalensi obesitas berhubungan dengan urbanisasi dan mudahnya mendapatkan makanan serta banyaknya mendapatkan makanan yang tersedia. ${ }^{1}$ 
World Health Organization (WHO) memperkirakan, di dunia ada sekitar 1.6 milyar orang dewasa berumur $\geq 15$ tahun kelebihan berat badan dan setidak-tidaknya sebanyak 400 juta orang dewasa obesitas pada tahun 2005, dan diperkirakan $>700$ juta orang dewasa akan obesitas pada tahun $2015 .^{2}$

Pada orang yang obesitas, ditemukan kadar asam lemak bebas yang tinggi dalam darah. Menikmati asam lemak bebas ini disebabkan oleh meningkatnya pemecahan trigliserida (proses lipolisis) di jaringan lemak. Asam lemak bebas yang tinggi berperan terhadap terjadinnya resistensi insulin. ${ }^{3}$ Perkembangan resistensi insulin dan gangguan metabolisme glukosa biasanya terjadi secara bertahap, yang dimulai dengan peningkatan berat badan dan obesitas. ${ }^{4}$

Pada kebanyakan kasus DM tipe 2 terjadi diatas umur 30, seringkali di antara usia 50-60 tahun, dan penyakit ini timbul secara perlahan-lahan. Akan tetapi, akhirakhir ini dijumpai peningkatan kasus yang terjadi pada usia muda. Masalah ini berkaitan terutama dengan peningkatan prevalensi obesitas, yaitu faktor risiko terpenting untuk DMT2. ${ }^{4}$

Diabetes melitus (DM) adalah gangguan metabolisme yang secara genetis dan klinis termasuk heterogen dengan manifestasi berupa hilangnya toleransi karbohidrat. Diabetes melitus tipe 2 merupakan tipe DM yang paling sering terjadi. DM tipe 2 sering ditemukan pada orang-orang yang kelebihan berat badan karena kadar lemak yang tinggi, terutama pada daerah perut, diketahui menyebabkan tubuh menjadi resisten terhadap efek insulin. ${ }^{5,7}$

Resistensi insulin menyebabkan penurunan pengambilan glukosa oleh jaringan otot dan lemak serta ketidakmampuan hormon untuk menekan glukoneogenesisd hati. Obesitas, terutama obesitas sentral berhubungan langsung dengan derajat insulin. Disfungsi sel beta pada DM tipe 2 menunjukkan ketidakmampuan dari sel-sel ini untuk menyesuaikan diri sendiri terhadap kebutuhan dalam waktu lama dari resistensi insulin perifer dan peningkatan sekresi insulin. ${ }^{6}$

Dislipidemia adalah gangguan metabolisme lipid berupa peningkatan kadar kolesterol total , trigliserida (TG), low density lippoprotein (LDL), high density lipoprotein (HDL). ${ }^{7}$

Trigliserida yang dikandung oleh LDL akan dihidrolisis oleh enzim hepatic lipase (yang biasanya meningkat pada resistensi insulin) sehingga menghasilkan LDL yang kecil dan padat, yang dikenal dengan LDL kecil padat (small dense LDL). Partikel LDL ini sifatnya mudah teroksidasi, oleh karena itu sangat aterogenik. Trigliserida VLDL besar juga dipertukarkan dengan kolesterol ester dari HDL dan menghasilkan HDL miskin kolesterol ester tapi kaya trigliserida. Kolesterol HDL demikian lebih muda dikatabolisme oleh ginjal sehingga jumlah HDL serum menurun. ${ }^{8}$

Gambaran dislipidemi pada DM tipe 2 yang paling sering ditemukan adalah peningkatan kadar trigliserida (TG) dan penurunan HDL. Walaupun kadar LDL tidak selalu meningkat, tetapi partikel LDL akan mengalami penyesuaian perubahan (modifikasi) menjadi bentuk kecil dan padat yang bersifat aterogenik. ${ }^{7}$

\section{METODE PENELITIAN}

Metode ini menggunakan metode penelitian deskriptif dengan pendekatan cross sectional (potong lintang). Penelitian yang bersiat deskriptif analitik ini dilakukan selama 3 bulan yaitu dari bulan September-November 2013 di Poliklinik Endokrin Bagian/SMF Ilmu Penyakit Dalam RSUP. Prof. R.D. Kandou Manado. Dalam penelitian ini populasinya adalah pasien Diabetes Melitus Tipe 2 yang dating berobat di Poliklinik Endokrin RSU Prof. R.D. Kandou Manado dan sampelnya yaitu pasien Diabetes Melitus Tipe 2 yang berobat selama periode waktu bulan September - November 2013. Data yang dikumpulkan berasal dari data sekunder 
rekam medik pasien yang memiliki data HASIL PENELITIAN DAN BAHASAN

Pada penelitian ini, berdasarkan jenis kelamin, jumlah sampel yang didapat antara laki-laki dan perempuan tidak jauh berbeda. Frekuensi ini sebagian besar terjadi pada perempuan dengan jumlah 31 dari 53 orang $(58,5 \%)$, sedangkan pada laki-laki ditemukan 22 dari 53 orang. $(41,5 \%)$. Berdasarkan kategori usia, ratarata sampel yang didapat berusia 58,18 tahun pada laki-laki dan usia 53,68 tahun pada perempuan. Rata-rata lingkar pinggang 93,18 $\mathrm{cm}$ pada laki-laki dan $87,32 \mathrm{~cm}$ pada perempuan.

Lingkar pinggang adalah ukuran antripometri yang dapat digunakan untuk menentukan obesitas sentral. Lingkar pinggang dikatakan sebagai indeks yang berguna untuk menentukan obesitas sentral dan komplikasi metabolik yang terkait.. Kriteria ukuran lingkar pinggang untuk etnis Asia Selatan yaitu kelompok laki-laki > $90 \mathrm{~cm}$, sedangkan kelompok perempuan $>80 \mathrm{~cm}$ yang dapat dikatakan beresiko komplikasi metabolik salah satunya dislipidemia.

Hasil pengumpulan data diketahui bahwa 28,3\% laki-laki memiliki lingkar pinggang $\geq 90 \mathrm{~cm}$ dan sementara $43,4 \%$ sampel perempuan memiliki lingkar pinggang $\geq 80 \mathrm{~cm}$. Pada orang obesitas, terdapat peningkatan total lemak dalam tubuh. Simpanan lemak tubuh tersebut dapat terjadi di lemak subkutan (obesitas general) dan lemak viseral (obesitas sentral). Lemak viseral banyak terdapat dalam rongga perut yang dapat diketahui dari lingkar pinggang. Namun lemak viseral lebih kuat hubungannya terhadap dislipidemia aterogenik dibandingkan dengan lemak subkutan ${ }^{9}$.

Berdasarkan hasil pengumpulan data diketahui bahwa kebanyakan sampel memiliki profil lipid yang kurang baik. Dimana $15,1 \%$ sampel perempuan memiliki kadar kolesterol total $\leq 50 \mathrm{mg} / \mathrm{dl}$ dan 13,2\% sampel laki-laki juga demikian. $58,5 \%$ sampel memiliki kadar koleterol $\geq 200 \mathrm{mg} / \mathrm{dl}, \quad 81,1 \%$ kadar LDL $\geq 100$ $\mathrm{mg} / \mathrm{dl}$, dan $47,2 \%$ kadar trigliseridanya lengkap.

$\geq 150 \mathrm{mg} / \mathrm{dl}$. Profil lipid tersebut dipengaruhi oleh gaya hidup, metabolisme dan konsumsi makanan.

Berdasarkan hasil uji analisis bivariat, ditemukan hubungan yang signifikan antara lingkar pinggang dengan kadar HDL. Dari hasil analisis ditemukan $p=0,015$. Hasil ini sesuai dengan penelitian oleh Zhu, et. al., dan beberapa penelitian terdahulu dimana lingkar pinggang mempunyai hubungan yang signifikan dengan kadar HDL.

Hasil analisis bivariat, ternyata tidak ditemukan hubungan yang signifikan antara lingkar pinggang dengan kadar trigliserida. Dari hasil analisis ditemukan $\mathrm{p}=0,474$ dan koefisien korelasi $r=0,100$. Hasil ini tidak sesuai dengan penelitian di Makassar oleh Suhuyanly, dimana lingkar pinggang mempunyai hubungan yang signifikan dengan kadar trigliserida ${ }^{10}$.

Pada penelitian ini dengan uji analisis bivariat untuk mencari korelasi lingkar pinggang dengan kolesterol total, kadar LDL, kadar trigliserida tidak ditemukan hubungan yang signifikan. Hasil ini didukung oleh hasil penelitan Fita Kaulina di Semarang yang juga menyatakan bahwa tidak ada hubungan yang signifikan antara lingkar pinggang dengan profil lipid. Perlu dipertimbangkan untuk memilih bentuk penelitian longitudinal dengan jumlah sampel yang kebih besar dalam mencari korelasi lingkar pinggang dengan profil lipid.

\section{SIMPULAN}

Pada penelitian ini tidak dijumpai hubungan yang signifikan antara lingkar pinggang dengan kadar kolesterol total, kadar LDL, dan kadar trigliserida. Namun terdapat hubungan yang signifikan antara lingkar pinggang dengan kadar HDL.

\section{SARAN}

Perlu dilakukan studi lebih lanjut untuk melihat kelompok nilai lingkar pinggang yang mempengaruhi kadar profil lipid.

\section{DAFTAR PUSTAKA}

1. Soegondo, S. Obesitas. Dalam : Buku Ajar 
Penyakit Dalam. Ed ke-5 Jilid III. Jakarta: Interna publishing, 2009, p. 1919-24.

2. RISKESDAS.Jakarta: Litbangkes: 2007.

3. Yuliasih, W. Obesitas Abdominal Sebagai Risiko Peningkatan Kadar Glukosa Darah. Artikel Penelitian.

4. Guyton, A. C. Hall, J. Dalam: Buku Ajar Fisiologi Kedokteran: Metabolisme Lipid, Edisi 11. Jakarta: Penerbit Buku Kedokteran EGC, 2007. p. 882-8.

5. Schteingart, D. Pankreas Metabolisme Glukosa dan Diabetes Melitus. Dalam: Buku Patofisiologi Konsep Klinis Proses-Proses Penyakit. Edisi 6 Volume 2. Jakarta: 2006. p. 1259-66

6. Lintong, P. Buku Patologi Sistem Endokrin. 2006. Manado: Bagian Patologi Fakultas Kedokteran Universitas Sam Ratulangi Manado
7. Lipid Profile In Type 2 Diabetic Mellitus Patient's. In: Diabetes Care.

8. Adam, J. Dislipidemia. Dalam: Buku Ajar Penyakit Dalam. Edisi 5. Jilid III. Jakarta. Interna Publishing, 2009; 1984-92

9. Suparjo HP. 2010. Hubungan Rasio Lingkar Pinggang dengan Profil Lipid pada Pasien PJK di Poliklinik Jantung RSUD dr. Moewardi Surakarta. Skripsi. Diterbitkan, Fakultas Ilmu Kesehatan Universitas Muhamadiyah, Surakarta.

10. Syukran,A., Mardianto, Lindarto, D., dkk. 2004. Sindroma metabolic pada karyawan/ staf perkebunan. Naskah Lengkap The Mets, Surabaya Metabolic Syndrome Update-1 (SUMETSU-1) 1 